\title{
PERFORMANCE EVALUATION OF MUTUAL AND PENSION FUNDS TRADED ON BORSA ISTANBUL UNDER THE CONTROL OF FUND COSTS
}

DOI: 10.17261/Pressacademia.2015414371

\section{Seher Goren', Mehmet Umutlu²}

'Yaşar University. seher.goren@yasar.edu.tr

${ }^{2}$ Yaşar University. mehmet.umutlu@yasar.edu.tr

\section{Keywords}

Mutual funds, pension funds, CAPM, Fama French three factor model, Jensen Alpha.

JEL Classification G10, G11, G23

\begin{abstract}
In this study, the performances of 10 groups of $A$ and $B$ Type mutual funds and the performance of the Pension (total) fund are evaluated at daily and monthly frequencies. Different from many studies aiming to evaluate fund performance, this study takes into account the expense ratios in calculating the net returns of fund groups. Whether the fund groups provide return that is proportional to risk is tested by using Capital Asset Pricing Model (CAPM) and the Fama - French three factor model. Jensen Alpha which is a risk-adjusted performance measure is obtained from the aforementioned asset pricing models and is used to test whether fund groups provide abnormal return. Consequently, contrary to the expectations, a great majority of funds evaluated under the control of expenses do not exhibit high performance.
\end{abstract}

\section{BORSA ISTANBUL'DA IŞLEM GÖREN YATIRIM VE EMEKLILIK FONLARININ FON GIDERLERI ETKISI ALTINDA PERFORMANS DEĞERLENDIRMESi ${ }^{1}$}

\begin{abstract}
Anahtar Kelimeler
\section{ÖZET}

Yatırım fonları, emeklilik fonları, SVFM, Fama -

French üç faktör modeli, Jensen Alfa.

Bu çalışmada, onar adet A veB Tipi yatırım fonugruplarının ve Emeklilik (toplam) fonu grubunun günlük ve aylık frekansta performansları ölçülmüştür. Fonların performansını ölçmeye yönelik diğer birçok çalışmadan farklı olarak, bu çalışma fon gruplarının net getiri oranlarınınhesaplanmasında gider oranlarını da göz önünde bulundurmuştur.Fon gruplarının riskleri ile orantılı bir getiriye sahip olup olmadığı, sermaye varlıklarını fiyatlama modeli (SVFM) ve Fama - French üç faktör modeli kullanılarak test edilmiştir. Riske karşı düzeltilmiş performans ölçütü olan Jensen Alfa ölçütü, yukarıda bahsedilen varlık fiyatlama modellerin tahminlenmesinden

JEL Sınıflandırması elde edilmiş ve fon gruplarının anormal bir getiriye sahip olup olmadıkları test G10, G11, G23 etmek için kullanılmıştır. Sonuç olarak, giderleri hesaba katılarak değerlendirilen fonların büyük çoğunluğu beklenilenin aksine yüksek performans göstermemiştir.
\end{abstract}

\footnotetext{
${ }^{1}$ Bu çalışma, 2015 yılında gerçekleştirilen 19. Ulusal Finans Sempozyumu'nda sunulan bildirinin genişletilmiş halidir.
} 


\section{GiRiş}

Çalışma kapsamında, Türkiye'de faaliyet göstermekte olan 9 türde A Tipi, 9 türde B Tipi olmak üzere 18 farklı türde yatırım fonu ve ayrıca A Tipi (toplam), B Tipi (toplam) yatırım fonları ve Emeklilik (toplam) fonlarının tamamından oluşan fon gruplarının, pazar getirisinden farklı bir getiri sağlayıp sağlamadıkları test edilerek pazar endeksine göre performansları ölçülmüştür. Bu amaç doğrultusunda, söz konusu fon gruplarının getirileri, Sermaye Varlıkları Fiyatlama Modeli (SVFM) ve Fama - French üç faktör modeli ile açıklanmaya çalışılmıştır. Bu modellerin tahminlenmesinden elde edilen ve sistematik riske karşı düzeltilmiş performans ölçütü olan Jensen Alfa ölçütü kullanılarak, fonların anormal bir getiriye sahip olup olmadıkları test edilmiştir.

Çalışma kapsamında, performans ölçümü için yatırım ve emeklilik fonlarının seçilmesinin önemli nedenleri vardır. Öncelikle, fonların profesyonel yöneticiler tarafından yönetilmesi, pazar hakkında gerekli bilgilerin zamanında edinilmesini ve piyasa öngörüsünün daha profesyonel olarak yapılmasını sağlamaktadır. Ayrıca fonların içerdiği menkul kıymetler çeşitlendirilerek, bireysel olarak yapılamayan risk yönetimi yapılmakta ve riskin en aza indirgenmesi mümkün hale gelmektedir. Bunların yanında, fona katılanlara, kurumlar vergisinden muaf olmaları sebebiyle, vergi avantajı sağlanmaktadır. Bu nedenler sebebiyle, fonlar aracılığıyla yatııı yapmanın, bireysel yatırım yapmaya göre daha yüksek bir getiri performansı sağlaması beklenmektedir. Buna rağmen, literatürde fonların performanslarının beklendiği gibi yüksek olmadığını gösteren ampirik çalışmalar da vardır. Bu çalışmalara; Blake, Elton ve Gruber (1993), Malkiel (1995), Karatepe ve Karacabey (2000), Gürsoy ve Erzurumlu (2001), Arslan (2005), Korkmaz ve Uygurtürk (2009), Omağ (2010), Aşcı ve Erzurumlu (2012) ve Ayaydın (2013)'ın çalışması örnek gösterilebilmektedir. Literatürde fonların performansı hakkında bir fikir birliği oluşturacak yeterli deneysel bulgu bulunmadığından, bu konunun açıklığa kavuşturulması için daha gerçekçi varsayımlarla elde edilmiş yeni ampirik bulgulara ihtiyaç vardır.

Yapılan literatür araştırmasından anlaşıldığı kadarıyla, BIST üzerine yapılan önceki çalışmalarda fon giderleri performans ölçüm işlemine dâhil edilmemiştir. Bu çalışmada, giderler fonların performans ölçümü için yapılan analizlerde ele alınmış ve fonların performansları analiz edilmiştir. Giderlerin dâhil edilmesiyle, gelir elde ettiren bazı fonların daha düşük bir pozitif getiriye ve hatta negatif bir getiriye sahip olup olmayacağı araştırılmıştır. Performans ölçütü olarak Jensen (1968) tarafından geliştirilmiş, Jensen Alfa kullanılmıştır. Söz konusu ölçüt, çeşitli varlık fiyatlama modelleri tahminlemesinde kullanılan regresyon denklemlerinden elde edilen regresyon sabitidir. Fon performanslarının birbirleriyle karşılaştırılmasından çok, alfa kriterine göre ayrı ayrı değerlendirilmesini sağlayan Jensen Alfa ölçütünün tercih edilmesinin en önemli sebebi, fon performanslarını riske göre düzeltilmiş olarak ölçmesidir. Dolayısıyla, risk ve getiri aynı anda hesaba katılmaktadır.

Bu çalışmada, Jensen Alfa ilk olarak Sharpe (1964), Lintner (1965) ve Mossin (1966) in geliştirdiği SVFM kullanılarak tahminlenmiştir. İkinci olarak, bu ölçütü tahminlemek için Fama ile French (1993)'in uyguladığı ve hisse senedi getirileri üzerinde piyasa getirisi, hisse senedi piyasa değerleri ve fiyat kazanç oranı faktörlerinin dâhil edildiği üç faktör modeli 
kullanılmışır. Böylece Jensen Alfa farklı modellerle tahminlenmiş ve sonuçların kullanılan modele göre hassasiyet gösterip göstermediği araştırılmışır.

Bu çalışmanın, literatüre en önemli katkısı, fonlarının net getiri oranlarının, ham getiri oranlarından gider oranlarının çıkarıımasıyla elde edilmiş olmasıdır. Yani, çalışmada diğer birçok çalışmadan farklı olarak, fon gruplarının net getiri oranları ortaya çıkarılırken, gider oranları da hesaba katılmıştır. Bu durum, fon performansının daha gerçekçi olarak hesaplanmasında büyük önem arz etmektedir. Çünkü giderler hesaba katılarak değerlendirilen fon gruplarının performansı daha düşük olabilecek fakat giderler dâhil edilmeden hesaplanan performans yanlı olarak daha yüksek gözükebilecektir. Dolayısıyla, fon giderleri düşünülmeden yapılacak olan bir yatırım, yatırımcıyı zarara uğratabilmektedir.

Hem günlük hem aylık dönemlerde analiz edilen fon gruplarının gider verileri sadece Ocak 2001 - Aralık 2010 tarihleri arasında elde edildiği için, çalışmadaki fon gruplarına ait en uzun tarih aralığı bahsedilen şekilde sınırlandııımıştır. Bazı fon grupları belli tarihlerde işlemde olmadıkları için onların analiz edildikleri tarih aralığı daha kısa tutulmuştur. Sermaye Piyasası Kurulu'nda adı geçen fonların tamamı analiz edilememiştir. Bunun sebebi, analiz edilemeyen fonların bazılarının ham getirisi hesaplanırken kullanılan verilerinin; bazılarının da gider verilerinin birçoğunun eksik olmasıdır.

Yatırım ve emeklilik fonlarının performans analizinin yapılmasının yatııımcılar açısından bazı faydaları bulunmaktadır. Öncelikle bu analiz, fonların performanslarının karşılaştırılmasına ve her birinin performansının pazar endeksine göre değerlendirilmesine olanak sağlamaktadır. İkinci olarak, bu değerlendirme yapilırken, fon gruplarının giderlerinin de hesaba katılması ile yatırımcıların fon performansı ile ilgili daha gerçekçi sonuçlara ulaşması mümkün olmakta ve yatııı kararlarındaki kalitenin artması sağlanmaktadır. Bu yüzden çalışmanın sonuçlarının, yatııımcıları ve finansal analistleri yakından ilgilendireceği düşünülmektedir.

Bulgularımız veri frekansına, Jensen Alfa ölçütünü tahminlerken kullanılan farkıı varlık fiyatlama modellerine ve Fama French 3 faktör modelindeki faktörler oluşturulurken kullanılan ağırıklandırma yöntemlerine bağlı olmaksızın tutarlı sonuçlar sunmaktadır. Buna göre, 21 fon grubu arasından 3 fon grubu neredeyse tüm regresyon analizi sonuçlarında; 1 fon grubu ise, sadece günlük dönemlerle yapılan SVFM analizi sonuçlarında yüksek performans göstermiştir. Dolayısıyla, gider oranları da hesap edilerek yapılan analizlerde, fonların büyük çoğunluğu pazar endeksine göre yüksek performans göstermemiş̧ir.

Çalışmanın geri kalan kısmı şu şekilde organize edilmiştir. Çalışmanın ikinci bölümünde, çeşitli fonların performans ölçümü üzerine geçmişte yapılan çalışmalar ve bu çalışmalarda kullanılan yöntemler ele alınmıştır. Üçüncü bölümde, analizler için kullanılan veri setleri ve yöntemler açıklanmıştır. Dördüncü bölümde, çalışmada yapılan analizlerin sonucunda elde edilen bulgular yer almaktadır. Beşinci bölümde ise, çalışmadan elde edilmiş sonuçlar değerlendirilmiştir. 


\section{TÜRKIYE'DE YATIRIM VE EMEKLILIKK FONLARI}

Sermaye Piyasası Kurulu Yatırım Fonları Bilgilendirme Kitapçı̆̆ı'na göre yatırım fonları 2 ayrı tipte ve 17 türde olup Emeklilik fonları yatırım stratejilerine göre çeşitli alt gruplara ayrılmaktadır. Tip olarak "A Tipi yatırım fonları” ve "B Tipi yatırım fonları" olmak üzere ikiye ayrılan yatııı fonlarının tipleri içerdikleri varlıklara göre belirlenmektedir. Türkiye'de Sermaye Piyasası Kurulu'na göre tür olarak altın fonu, değişken fon, endeks fon, fon sepeti fonu, garantili fon, grup fonu, hisse senedi fonu, iştirak fonu, karma fon, kıymetli madenler fonu, koruma amaçlı fon, likit fon, özel fon, sektör fonu, serbest yatırım fonu, tahvil ve bono fonu ve yabancı menkul kıymetler fonu olmak üzere 17'ye ayrılan yatırım fonlarının türleri portföye alınacak olan menkul kıymetlere göre belirlenmektedir. Sermaye Piyasası Kurulu'nun 10.05.2002 tarih ve 22 / 646 sayılı kararı gereğince emeklilik yatırım fonu türleri; gelir amaçlı fonlar, büyüme amaçlı fonlar, kıymetli maden fonları, ihtisaslaşmış fonlar, para piyasası fonları ve diğer fonlar olmak üzere altı sınıfta toplanmaktadır. Daha sonra söz konusu bu fonlar başlıca; esnek fon, likit fon, standart fon, hisse senedi fonu, altın fonu, karma fon, karma borçlanma araçları fonu, dengeli fon, özel sektör borçlanma araçları fonu olarak genişlemiştir (Sermaye Piyasası Kurulu Yatırımcı Bilgilendirme Kitapçı̆̆ı).

\subsection{Yatırım Fonları}

Yatırım fonları, bir yatırım aracı olarak kendini gösterdiğinden bu yana, portföy çeşitliliğiyle birlikte günümüze kadar gelmiş ve gelişerek yaygınlaşmıştır. Daha çok 2000'li yıllarda gelişim göstermiştir. Sermaye Piyasası Kurulu'nun "Yatırım Fonlarının Tarihsel Konsolide Portföy Bilgileri” verilerine göre 1990 yılında 71 tane olan fonların sayısı, 1994 yılında 90'a, 1997 yılında 156'ya, 2001 yılında 293'e, 2008 yılında 340'a ulaşırken 2014 Aralık ayı verilerine göre 2014 yılında 482'yi bulmuştur (Sermaye Piyasası Kurulu Aylık İstatistik Bülteni).

Tablo 1: A Tipi Fonların Portföy Değerleri (Milyon TL)

\begin{tabular}{|c|c|c|c|c|c|c|}
\hline & & & & & & $114 / 2013$ \\
\hline & 2010 & 2011 & 2012 & 2013 & 2014 & Değișim \\
\hline Karma Fon & 371 & 352 & 419 & 411 & 468 & $13.9 \%$ \\
\hline Deḡișken Fon & 269 & 269 & 324 & 344 & 335 & $-2.6 \%$ \\
\hline Endeks Fon & 315 & 260 & 273 & 301 & 316 & $5.0 \%$ \\
\hline Pay Senedi Fonu & 167 & 172 & 225 & 356 & 250 & $-29.8 \%$ \\
\hline Iștirak Fonu & 150 & 221 & 128 & 164 & 234 & $42.7 \%$ \\
\hline Ozel Fon & 137 & 139 & 185 & 188 & 204 & $8.5 \%$ \\
\hline Borsa Yaturım Fonu & 77 & 49 & 67 & 76 & 85 & $11.8 \%$ \\
\hline Yabancı MK Fonu & 1 & 1 & 1 & 3 & 9 & $249.0 \%$ \\
\hline Sektör Fonu & 0.2 & 0.2 & 0.4 & 0.2 & 0.3 & $50 \%$ \\
\hline Fon Sepeti Fonu & 5 & 5 & 0 & 0 & 0 & A.D. \\
\hline Serbest Yatırım Fonu & - & - & - & 1 & 0 & A.D. \\
\hline Toplam & 1,492 & 1,468 & 1,624 & 1.844 & 1.901 & $3.1 \%$ \\
\hline
\end{tabular}

Kaynak:Takasbank, http://www.tspb.org.tr/tr/Portals/0/AIM_Yillik/TSP_2014_web_opt\%20R.pdf 
Tablo 1, A Tipi fonların portföy değerlerini milyon TL cinsinden göstermektedir. 2013 ve 2014 yılı incelendiğinde Karma fon, endeks fon, iştirak fonu, özel fon, borsa yatırım fonu, yabancı menkul kıymetler fonu ve sektör fonunun portföy değerleri artarken; değişken fon ve pay senedi fonunun portföy değerleri azalmıştır.

Tablo 2: B Tipi Fonların Portföy Değerleri (Milyon TL)

\begin{tabular}{|l|r|r|r|r|r|r|}
\hline & 2010 & 2011 & 2012 & 2013 & 2014 & $\begin{array}{r}2014 / 2013 \\
\text { Değișim }\end{array}$ \\
\hline Kısa Vadeli Tahvil Fonu & - & - & 4,618 & 12,215 & 12,998 & $6.4 \%$ \\
\hline Likit Fon & 22,877 & 20,555 & 17,036 & 11,005 & 12,622 & $14.7 \%$ \\
\hline Değişken Fon & 1,906 & 1,279 & 2,263 & 2,419 & 3,505 & $44.9 \%$ \\
\hline Tahvil ve Bono Fonu & 2,252 & 1,269 & 2,231 & 1,560 & 2,840 & $82.1 \%$ \\
\hline Serbest Yatınm Fonu & 214 & 162 & 244 & 580 & 935 & $61.3 \%$ \\
\hline Ozel Fon & 251 & 246 & 279 & 278 & 456 & $63.9 \%$ \\
\hline Altın \& Diğer Kry. Mad. Fonu & 479 & 1,346 & 835 & 512 & 364 & $-28.8 \%$ \\
\hline Koruma Amaçlı Fon & 2,112 & 2,846 & 923 & 460 & 162 & $-64.9 \%$ \\
\hline Yabancı MK Fonu & 126 & 100 & 100 & 129 & 142 & $10.0 \%$ \\
\hline Borsa Yatırım Fonu & 164 & 238 & 306 & 105 & 107 & $2.5 \%$ \\
\hline Fon Sepeti Fonu & 8 & 16 & 14 & 24 & 49 & $107.8 \%$ \\
\hline Garantili Fon & 415 & 772 & 77 & 53 & 22 & $-58.6 \%$ \\
\hline Karma Fon & 4 & 4 & 0 & 5 & 13 & $164.6 \%$ \\
\hline Altın Fonu & - & - & 3 & 3 & 2 & $-12.3 \%$ \\
\hline Toplam & 30,807 & 28,832 & 28,930 & 29,346 & 34,217 & $16.6 \%$ \\
\hline
\end{tabular}

Kaynak:Takasbank, http://www.tspb.org.tr/tr/Portals/0/AIM_Yillik/TSP_2014_web_opt\%20R.pdf

Tablo 3: Yatırım Fonları Sayıları ve Portföy Büyüklükleri

\begin{tabular}{|c|c|c|c|c|c|c|}
\hline \multirow[b]{2}{*}{ Fon Sayıları } & \multirow[b]{2}{*}{2010} & \multirow[b]{2}{*}{2011} & \multirow[b]{2}{*}{2012} & \multirow[b]{2}{*}{2013} & \multicolumn{2}{|c|}{$2014 / 2013$} \\
\hline & & & & & 2014 & Değișim \\
\hline A Tipi Fonlar & 119 & 123 & 122 & 122 & 120 & $-1.6 \%$ \\
\hline B Tipi Fonlar & 307 & 343 & 333 & 324 & 294 & $-9.3 \%$ \\
\hline Emeklitik Yatırım Fonları & 140 & 165 & 175 & 233 & 245 & $5.2 \%$ \\
\hline Toplam & 566 & 631 & 630 & 679 & 659 & $-2.9 \%$ \\
\hline \multicolumn{7}{|c|}{ Portfōy Büyüklükleri (Milyon TL) } \\
\hline A Tipi Fonlar & 1.492 & 1,468 & 1,624 & 1,844 & 1,901 & $3.1 \%$ \\
\hline B Tipi Fonlar & 30,807 & 28,832 & 28,930 & 29.346 & 34,217 & $16.6 \%$ \\
\hline Emeklitik Yatırım Fonları & 12,177 & 14,308 & 20,343 & 26,364 & 38,030 & $44.2 \%$ \\
\hline Toplam & 44,476 & 44,608 & 50,897 & 57,554 & 74.149 & $28.8 \%$ \\
\hline
\end{tabular}

Kaynak: Takasbank, http://www.tspb.org.tr/tr/Portals/0/AIM_Yillik/TSP_2014_web_opt\%20R.pdf

Tablo 2, B Tipi fonların portföy değerlerini milyon TL cinsinden göstermektedir. 2013 ve 2014 yılı incelendiğinde kısa vadeli tahvil fonu, likit fon, değişken fon, tahvil ve bono fonu, serbest yatıım fonu, özel fon, yabancı menkul kıymetler fonu, borsa yatırım fonu, fon sepeti fonu ve karma fonun portföy değerleri artarken; altın ve diğer kıymetli madenler fonu, koruma amaçlı fon, garantili fon ve altın fonunun portföy değerleri azalmıştır. 
Tablo 3, 2010 yılından 2014 yılına kadar olan yatırım fonlarının sayılarını ve portföy büyüklüklerini göstermektedir. 2013 yılından 2014 yılına geçerken toplam fon sayısı 679'dan 659'a düşmesine rağmen, fon büyüklüğü \%28,8'lik bir artışla yaklaşık 58 milyar TL'den 74 milyar TL'ye yükselmiştir. Son 5 yılda A Tipi fon portföy büyüklüğünde ciddi bir değişiklik olmamıştır. 2014 yılının sonucuna bakıldığında yaklaşık olarak 2 milyar TL'lik A Tipi fon yönetilmiştir. B Tipi fonların da büyüklüğü yıllar içinde önemli bir değişiklik yaşamamıştır. Ancak 2014 yılı sonunda 34 milyar TL'ye çıkmıştır. Bu değer de \%17'lik bir artışa tekabül etmektedir.

\subsection{Emeklilik Fonları}

Emeklilik fonları, bireysel emeklilik şirketleri tarafından, tasarruf sahiplerinin katkı amacıyla ödedikleri paylarının kendi hesaplarında değerlendirilmesi amacıyla kurulmuş olan ve gelir getiren farklı sermaye piyasası araçlarından oluşan yatırım araçlarıdır. Kurulmuş olan fonlar sadece bireysel emeklilik sistemine üye olan yatırımcılara yöneliktir ve bu süreç Türkiye'de gönüllü olarak işlemektedir. Kişiler, istedikleri takdirde emeklilik fonlarına yatırım yapmaktadırlar. Herhangi bir zorunluluk söz konusu değildir (Bireysel Emeklilik Sistemi Bilgilendirme Sitesi).

Tablo 4: Emeklilik Yatırım Fonlarının Büyüklük Dağılımı (Milyon TL)

\begin{tabular}{|l|r|r|r|r|r|r|r|}
\hline & 2010 & 2011 & 2012 & 2013 & 2014 & $\begin{array}{r}2014 / 2013 \\
\text { Değisim }\end{array}$ \\
\hline Kamu Borçlanma Araçlan (TL) & 6,482 & 7,211 & 10,146 & 10,209 & 12,721 & $24.6 \%$ \\
\hline Esnek Fon & 3,079 & 3,828 & 5,908 & 8,057 & 11,323 & $40.5 \%$ \\
\hline Likit Fon & 1,162 & 1,374 & 1,690 & 2,229 & 3,480 & $56.1 \%$ \\
\hline Standart Fon & - & - & - & 1,150 & 3,019 & $162.5 \%$ \\
\hline Hisse Senedi Fonu & 765 & 908 & 1,427 & 1,854 & 2,543 & $37.2 \%$ \\
\hline Kamu Borçlanma Araçlan (Yabancı Para) & 401 & 634 & 750 & 865 & 1,567 & $81.2 \%$ \\
\hline Altın Fonu & - & - & - & 84 & 301 & $258.3 \%$ \\
\hline Karma Fon & 132 & 150 & 213 & 182 & 275 & $51.1 \%$ \\
\hline Karma Borçlanma Araçlan Fonu & - & - & - & 100 & 162 & $62.0 \%$ \\
\hline Dengeli Fon & 123 & 111 & 121 & 118 & 123 & $4.2 \%$ \\
\hline Özel Sektör Borçlanma Araçları Fonu & - & - & 1 & 34 & 57 & $67.6 \%$ \\
\hline Endeks Fon & - & - & 19 & 37 & 33 & $-10.8 \%$ \\
\hline Uluslararası Fon & 33 & 91 & 68 & 186 & 21 & $-88.7 \%$ \\
\hline Devlet Katkısı Fonu & - & - & - & 1,259 & 2,407 & $91.2 \%$ \\
\hline Toplam & 12,177 & 14,308 & 20,343 & 26,364 & 38,031 & $44.3 \%$ \\
\hline
\end{tabular}

Kaynak:Takasbank, http://www.tspb.org.tr/tr/Portals/0/AIM_Yillik/TSP_2014_web_opt\%20R.pdf

Tablo 4, emeklilik fonlarının büyüklük dağılımını milyon TL cinsinden göstermektedir. 2010 yılının sonunda yaklaşık 12 milyar TL olan emeklilik fonlarının portföy büyüklüğü sürekli yükselmiş ve 2014 yılı sonunda 38 milyar TL olmuştur. 2014 yılında, Emeklilik fonları A ve B Tipi fonları ile kıyaslandığında, Emeklilik fonlarının portföy büyüklüğünün A ve B Tipi fonlarının toplam portföy büyüklüğünü geçmiş olduğu görülmektedir. Bu artışta, 2013 yılında getirilen devletin \%25 oranındaki katkısının da etkisi olduğu düşünülmektedir. Kamu borçlanma araçları fonları yaklaşık 13 milyar TL portföy büyüklüğü ile emeklilik fonları portföy değeri büyüklüğünde ilk sıradadır. İkinci sıradaki fon ise 11 milyar TL ile 
esnek fonlardır. Standart fonların büyüklügü ise 3 milyar TL'dir. 2013 yılında işleme konan devlet katkısı fonunun portföy büyüklüğü ise 2014 yılı sonunda 2,4 milyar TL'ye ulaşmıştır.

\section{LITERATÜR TARAMASI}

1950 yılı öncesinde portföy performansları sadece getiri oranı baz alınarak ölçülmekteydi. Yatırımcılar risk büyüklüğü ve nasıl ölçüleceği konusunda yeterince bilgiye sahip değillerdi. $\mathrm{Bu}$ sebeple, hem risk hem getiri temelli bir tercih yapmamaktaydılar. Markowitz (1952) modern portföy teorisinin temellerini atmış ve risk ile getiriyi aynı süreçte değerlendirmeye almıştır. 1960'ların başında portföy teorisi kavramının gelişmesiyle, risk faktörü de portföy performansı ölçümlerinde kendini göstermeye başlamıştır. Bu sürecin başında, Sharpe (1964) tarafından SVFM ortaya çıkarılmıştır. Belli bir varlığın risk ile getiri arasındaki ilişkisini ele alan bu model, daha sonra Lintner (1965) ve Mossin (1966) tarafından geliştirilerek literatürde 'Sharpe - Lintner - Mossin modeli' olarak yerini almıştır. Bu çalışmaların her birinde, Markowitz (1952)'in portföy teorisi temel alınmıştır. Illerleyen yıllarda, bazı çalışmalardaki analizlere farklı değişkenler dâhil edilerek de varlıkların performansları açıklanmak istenmiş ve çok faktörlü modeller oluşturulmuştur. Fama ve French (1992) zamana bağlı olarak hisse senetlerinin getirilerinin değişimini araştırmışlar ve bu getirileri, pazar portföyünün getirisine ek olarak, firma büyüklüğü ile defter değeri / piyasa değeri oranının da etkileyebileceğini ifade etmişlerdir. Elde ettikleri bu sonucu esas alan Fama ve French (1993), SVFM'ne iki faktörü de ilave etmişler ve SVFM'ne alternatif olarak üç faktörlü varlık fiyatlama modelini oluşturmuşlardır.

Literatürde SVFM'ne dayanan çeşitli portföy performansı değerlendirme yöntemleri oluşturulmuştur. Bu yöntemlerden biri de Jensen (1968) tarafından geliştirilmiştir. Jensen (1968) portföy performansının ölçülmesi için Jensen Alfa gibi belli bir ölçütü ortaya çıkarmıştır. Jensen (1968)'in SVFM'ni temel alarak geliştirdiği bu ölçüt, portföy performansını piyasa getirisine göre değerlendirmektedir. Jensen (1968), 1945 - 1964 yılları arasında işlem gören 115 yatırım fonunun performansını yıllık dönemlerle ölçmüş ve fonların çoğunlukla piyasadan daha yüksek performans göstermediği sonucuna ulaşmıştır. 1960'lı yıllardan başlayan portföy performansını ölçmeye yönelik çalışmaların çoğunluğunda, özellikle yatırım fonları, bu çalışmada olduğu gibi ele alındıkları ölçütlere göre düşük performans göstermişlerdir. Ortaya çıkan performans ölçütleri, dünyada ve Türkiye'de farklı bilim adamları tarafından fonların performansının ölçülmesine yönelik uygulama alanı bulmuşlardır.

Literatüdeki bazı çalışmalara bakılacak olursa, Grinblatt ve Titman (1989), 1975 - 1984 tarihleri arasında Amerika'da yatırım fonlarının performanslarını üçer aylık dönemlerle ölçmeye çalışmışlardır. Çalışma sonuçlarına göre, fonların genel olarak piyasadan yüksek performans gösterdiklerini ifade etmişlerdir. Cumby ve Glen (1990), 1982 - 1988 tarihleri arasında Amerika'da 15 adet uluslararası yatırım fonunun performansını ölçmeye çalışmışlar; fonların piyasaya göre yüksek performans sergilemediğini görmüşlerdir. Blake, Elton ve Gruber (1993) 1979 - 1989 tarih aralığında ulaşabildikleri aylık dönemlerle, Amerika'da 46 adet tahvil yatırım fonunun performansını alfa ölçütüne göre değerlendirmiş ve fonların büyük çoğunluğunun düşük performans gösterdiğini ifade etmiştir. Malkiel (1995) 1971 - 1991 tarihleri arasında yıllık dönemlerle Amerika'da yatırım 
fonlarını yönetim ve diğer bir takım giderleriyle birlikte ele almış bu giderlerle ele alınan fonlarda aktif olarak görülen yönetici çabalarının fonların ek bir getiri getirmesinde bir etkisi olmadığııı çalışmasında ortaya çıkarmıştır. Cesari ve Panetta (2002), 1985 - 1995 tarihleri arasında İtalya'da aylık dönemlerle yatııım fonlarının performansını incelemişler ve fonlarının alfa değerlerini 'sıfır' olarak bulmuşlardır.

Türkiye'deki bazı çalışmalara bakılacak olursa, Karatepe ve Karacabey (2000) 1997 - 1999 tarihleri arasında aylık dönemlerle 9 adet A Tipi yatırım fonu performansını yeni bir yöntemle ölçmüş ve Sharpe, Treynor ve Jensen yöntemlerini de kullanarak hepsinin sonuçlarını kıyaslamıştır. Sonuçlara göre yatııı fonları piyasadan daha düşük bir performans sergilemiştir. Gürsoy ve Erzurumlu (2001) 1998 - 2000 tarihleri arasında 55 A Tipi ve 77 B Tipi yatırım fonlarının performansını haftalık dönemlerle incelemişler ve fon yöneticilerinin pazar endeksinden yüksek performansta fonlar oluşturma çabalarının çok yararlı olmadığı sonucuna ulaşmışlardır. Arslan (2005) 2002 - 2005 tarihleri arasında olmak üzere 4 yıllık dönemi ele alarak 45 adet $A$ Tipi yatırım fonunun performansını ölçmüş ve fonların genellikle piyasaya göre düşük performans sergilediğini ifade etmiştir. Korkmaz ve Uygurtürk (2007) 2004 - 2006 tarihleri arasında 46 adet emeklilik fonunun performansını haftalık dönemlerle ölçmüşlerdir. Bunun sonucunda, fonlar tekli ve iki değişkenli analizlerde başarılı; üç değişkenli analizlerde başarısız olmuştur. Akel (2007), 2000 - 2004 tarihleri arasında aylık dönemlerle 51 adet A Tipi ve 51 adet B Tipi yatırım fonunun performansını ölçmüştür. Bunun sonucunda genel olarak A Tipi fonlar pazar endeksinin altında bir getiri sağlarken; B Tipi fonlar pazar endeksinin üzerinde bir getiri sağlamıştır. Altıntaş (2008), 2004 - 2006 tarihleri arasında aylık dönemlerle 36 adet emeklilik fonunun performansını incelemiş; inceleme sonunda genel olarak fon yöneticilerinin seçicilik yeteneklerinin olmadığını, yani fonların pozitif alfa değerine sahip olmadığını göstermiştir. Korkmaz ve Uygurtürk (2009) çalışmalarında 2006 - 2009 tarihleri arasında günlük dönemlerle işlem gören emeklilik, borsa yatırım ve A Tipi hisse senedi fonlarının fon performanslarını ve yönetici yeteneklerini saptamaya çalışmışlardır. Çalışmalarının sonucunda, yöneticilerin başarı gösteremediklerini ve sadece borsa yatırım fon grubuna dâhil edilen bir fonun yüksek performans gösterdiğini ifade etmişlerdir. Omağ (2010) 2000-2008 tarihleri arasında yıllık dönemlerle A Tipi ve B Tipi yatırım fonlarının performans analizini yapmış; fonların piyasaya göre düşük performans gösterdiğini savunmuştur. Arslan ve Arslan (2010), 2006 - 2010 tarihleri arasında A Tipi değişken fon, B Tipi değişken fon, A Tipi hisse senedi fonu ve A Tipi borsa yatııım fonlarından oluşan 4 grup yatııı fonunun günlük bazda performansları tespit etmeye çalışmıştır. Çıkan sonuçlarda, fonların tamamının pozitif alfa değerine sahip olduğu görülmüştür.

Aşcı ve Erzurumlu (2012) 2006 - 2010 tarihleri arasında aylık dönemlerle 79 adet fonu incelemiştir. Tahminlenen alfa değerlerine göre pozitif anormal getiri sağlayan fonların az miktarda olduğu yani fonların genellikle düşük performans sergilediği sonucuna ulaşmışır. Yolsal (2012), 2009 - 2012 tarihleri arasında 20 adet A Tipi yatııım fonunun günlük bazda performans analizini gerçekleştirmiştir. Sonuçlara göre alfa değeri anlamlı ve pozitif çıkan fon grupları çoğunluk göstermiştir. Gökgöz ve Günel (2012), 2008 - 2009 tarihlerinde; altışar aydan oluşan 4 dönemde A Tipi, B Tipi ve değişken fonlardan oluşan onar adet yatııım fonunun performansını ölçmüşlerdir. Analizleri sonucunda Jensen Alfa ölçütüne göre, fonlar analize tabi tutulan dönemlerinin yarısında pozitif getiri sağlamış; yarısında 
negatif getiri sağlamıştır. Ayaydın (2013) 2010 - 2013 tarihleri arasında aylık dönemlerle 34 adet Esnek ve Dengeli Emeklilik fonlarının performanslarını değerlendirmiştir. Sonuçlara göre, emeklilik fonlarının pazar performansına göre düşük performans gösterdiğini ifade etmiştir.

\section{VERI VE DEĞIŞKENLER}

Yatııım ve emeklilik fonlarının performanslarını ölçmeye yönelik bu çalışmada A ve B Tipi yatırım ve Emeklilik fonlarına ait toplam değer ve gider verileri, hazine bonosu getiri oranları, borsada işlem gören 100 şirkete ait hisse senedi getiri endeksi (XU100) ve son olarak BIST'de işlem gören, firmalara ait, hisse senetlerinin getiri verileri, piyasa değerleri ve fiyat kazanç oranları kullanılmıştır.

A ve B Tipi yatırım ve Emeklilik fonlarına ait toplam değer ve gider verileri Türkiye Cumhuriyeti Başbakanlık Sermaye Piyasası Kurulu resmi web sitesinden, hazine bonosu getiri oranları Türkiye Cumhuriyeti Merkez Bankası resmi web sitesinden, borsada işlem gören 100 şirkete ait hisse senedi getiri endeksi (XU100) Borsa İstanbul resmi web sitesinden ve BIST'de işlem gören, firmalara ait, hisse senetlerinin getiri verileri, piyasa değerleri ve fiyat kazanç oranları Thomson Reuters Eikon veri kaynağından alınmıştır.

Türkiye Cumhuriyeti Başbakanlık Sermaye Piyasası Kurulu resmi web sitesinde yer alan fonlara ait gider verilerinin tarih aralı̆ının Ocak 2001 - Aralık 2011 olması sebebiyle, çalışmadaki en uzun tarih aralı̆ı bu şekilde sınırlandırılmıştır. Fonlar bu tarih aralığında hem günlük hem de aylık dönemlerle analize tabi tutulmuştur. Bazı fonlar için, gereken verilerin tamamına ulaşılamaması veya belli tarihlerde fonun işlemde olmaması sebebiyle bu fonların analiz dönemleri daha kısadır. A Tipi (Toplam), A Tipi Değişken, A Tipi Endeks, A Tipi Hisse Senedi, A Tipi Iş̧tirak, A Tipi Karma, A Tipi Özel, B Tipi (Toplam), B Tipi Değişken, B Tipi Karma, B Tipi Likit, B Tipi Tahvil Bono, B Tipi Yabancı Menkul Kıymetler fon grupları Ocak 2001 - Aralık 2011; A Tipi Sektör fon grubu Ocak 2001 - Aralık 2011; B Tipi Özel fon grubu Ocak 2004 - Aralık 2011; A Tipi Yabancı Menkul Kıymetler fon grubu Şubat 2004 Aralık 2011; B Tipi Altın fon grubu Nisan 2007 - Aralık 2011; B Tipi Endeks fon grubu Eylül 2007 - Aralık 2011; A Tipi Fon Sepeti, B Tipi Fon Sepeti fon grupları Eylül 2008 - Aralık 2011 ve Emeklilik (Toplam) fon grubu Ocak 2005 - Aralık 2011 tarih aralı̆ıında ele alınmıştır.

Bu çalışma kapsamında ise 9 türde A Tipi; 9 türde B Tipi yatııım fonu ayrı ayrı ele alınmıştır. Bunlara ek olarak, Emeklilik fonlarının ve hem A Tipi hem B Tipi yatırım fonlarının tamamı ayrı 3 fon grubu şeklinde ele alınmıştır. Anlaşıldı̆̆ı üzere, analizin yapıldığı tarih aralığında Sermaye Piyasası Kurulu'nda adı geçen fonların tamamı analiz edilememiştir. Bu durumun öncelikli sebebi, analize dâhil edilmeyen fonların kendi içinde zaman serisinin farklılık göstermesidir. Söz konusu fonların ele alındıkları zaman aralı̆ı Ocak 2001 - Aralık 2011 olmasına rağmen, bu aralıktaki bazı tarihler için fonlara ait toplam değer verisi bulunmamaktadır. Diğer sebep ise, elde edilmesi gereken gider verilerinin, tarih aralığının tamamı için sağlanamamasıdır. Ocak 2001 - Aralık 2011 tarih aralığı için söz konusu fon grubuna ait toplam değer verilerine ulaşıırken, bu aralıktaki bazı tarihler için o tarihin gider verilerine ulaşılamamıştır. Sonuç olarak, tüm örneklem periyodu için toplam değer ve gider verisi süreklilik göstermeyen fonlar örnekleme dâhil edilmemiştir. 
Sermaye Piyasası Kurulu'na göre, bir fona ait "portföy değeri", herhangi bir iş günü için portföye ait varlıkların işlem görüp alım ve satımının yapıldığı borsalardaki fiyatlar ele alınarak hesap edilmektedir. Fon portföy değerinden de söz konusu fonun borçları düşülüp, alacakları da eklenerek fonun "toplam değeri" ortaya çıkarılmaktadır (SPK Yatırımcı Bilgilendirme Kitapçıkları 3, 2010: 9). Bu sebeple, çalışma kapsamında yatırım ve emeklilik fonlarının ham getiri oranları hesap edilirken günlük portföy değeri yerine, günlük toplam değer verileri baz alınmış ve Denklem (1) kullanılmıştır. Ham getiri oranı denmesinin sebebi henüz risksiz faiz oranının (risksiz getiri oranı) ve fonların gider oranlarının bu orandan çıkarılmamasıdır.

$$
\text { Getiri oranı }=\frac{\text { Toplam de } \mathrm{g} e r_{t+1}}{\text { Toplam değer }_{t}}-1
$$

Denklemde fon toplam değerinin $t+1$ dönemi $t$ döneminden sonraki dönemi göstermektedir. Bu da günlük hesaplamalar için 1 iş gününe, aylık hesaplamalar için 1 aya tekabül etmektedir. Risksiz faiz oranı olarak da üç aylık hazine bonosu getiri oranları kullanılmıştır. Bu getiri oranlarından risksiz faiz oranları günlük olarak hesap edilirken Denklem (2) kullanılmıştır.

$$
r_{f}=\left(1+r_{f y}\right)^{1 / 252-1}
$$

Denklemde $r_{f}$ risksiz faiz oranını, $r_{f y}$ yıllık bileşik faiz oranını ifade etmektedir. 252 sayısı bir yıldaki iş gününü göstermektedir. Dolayısıyla, Denklem (2)'de günlük olarak hesap edilen risksiz faiz oranları, aylık olarak hesap edilirken bir yılda 12 ay olması sebebiyle 252 sayısı yerine 12 sayısı getirilerek hesaplanmıştır.

$\mathrm{Bu}$ çalışmadaki en önemli veri setini ise yatırım ve emeklilik fonlarının gider verileri oluşturmaktadır. Çünkü bu çalışmanın literatüre katkısı, fonların ham getiri oranlarının gider oranlarından arındırılmasıyla elde edilen net getiri oranlarının kullanılmasıdır. Dolayısıyla, fonların net getiri oranları hesaplanırken gider oranlarının analize dâhil edilmesi söz konusu çalışmayı literatürde diğer birçok çalışmadan ayırmaktadır. Fonların artık net getiri oranları, ham getiri oranlarından gider ve risksiz faiz oranlarının çıkarılmasıyla elde edilmiştir. Fonların net getiri oranlarının giderler düşülerek hesap edilmesi, yapılan analizlerin yatırımcıya daha doğru bir yol göstermesine sebep olmaktadır. Çünkü fonların giderleri ele alınarak yapılan analiz sonuçları ile giderler ele alınmadan yapılan analiz sonuçları farklılık gösterebilmektedir. Çalışmada, Sermaye Piyasası Kurulu'ndan yıllık olarak sunulan çeşitli gider verileri gruplar halinde toplanarak her bir fon için toplam gider hesap edilmiştir. Bu gider grupları ihraç izni giderleri, ilan giderleri, sigorta ücretleri, aracılık komisyonu giderleri toplamı, noter harç ve tasdik giderleri, fon yönetim ücreti, bağımsız denetim ücreti, katılma belgesi basım giderleri, vergi, resim, harç ve benzeri giderler, saklama giderleri ve diğer gider gruplarından oluşmaktadır. Ardından her bir fonun toplam gideri fonun toplam değerine bölünerek yıllık gider oranı bulunmuştur. Daha sonra, yıllık gider oranı o fonun bir yılda işlem gördüğü güne ve aya bölünerek günlük ve aylık gider oranı hesap edilmiştir. Böylece, diğer birçok çalışmadan farklı olarak fonların net getiri oranları bulunurken gider oranları da hesaba katılmıştır. 
Portföy performansını ölçmek için uygulanan regresyon analizlerindeki varlık fiyatlama modellerinde şu değişkenler kullanıımışır: Bağımlı değişken olarak yatıım ve emeklilik fonları getiri oranı; bağımsız değişkenler olarak ise piyasa risk primi $\left(R_{M}\right)$, ele alınan 239 şirkete ait olan küçük ve büyük piyasa değerine sahip hisse senedi portföylerinin getirileri arasındaki fark $(S M B)$, yüksek ve düşük fiyat kazanç oranına sahip hisse senedi portföylerinin getirileri arasındaki fark $(H M L)$ kullanılmışır. Piyasa risk primi, piyasada işlem gören riskli hisse senetlerinin beklenen getirisinden risksiz faiz oranın çıkarılmasıyla elde edilmektedir. Herhangi bir hisse senedine ait piyasa değeri, şirketin o hisse senedinin fiyatı ile hisse senedi sayısının çarpılmasıyla ortaya çıkmaktadır. Fiyat kazanç oranı hesaplanırken ise, belli bir hisse senedinin piyasa fiyatı hisse başına düşen kâra bölünmektedir.

\section{YÖNTEM}

Çalışmada Sermaye Piyasası Kurulu'nda yer alan yatııım ve emeklilik fonlarının gider verileri dikkate alınarak, fon getirilerinin ortalama piyasa getirisinden farklılaşıp farklılaşmadığı analiz edilmiş ve piyasaya göre gösterdikleri performansları tespit edilmeye çalışılıı̧ıı. Yatıım ve emeklilik fonlarının performanslarının değerlendirilmesi, getirileri baz alan yatırımcılara yol göstermesi açısından önem arz etmekte ve fonların karşılaştııılmasına imkân vermektedir. Ancak herhangi bir fon, harcanan giderler ele alınmadan pozitif getiri sağlıyor gözükürken; giderler de ele alındığı takdirde durum tersine dönebilmekte ve negatif getirilere sebep olabilmektedir. Bu da giderler dâhil edilmeden performansı ölçülen fonun yatırımcıyı yanıltmasına sebep olmaktadır. Bu yüzden, bu çalışmada fonların performansı ölçülürken ölçüme dâhil edilen fon giderleri büyük önem taşımaktadır.

Herhangi bir fonun performansının sadece getiri oranına bakılarak belirlenmesi hatalı bir yaklaşım olacaktır. Risk ve getiri bir arada düşünülmeli, fonun risk birimi başına getirisi hesaplanmalıdır. Pazar endeksi ve portföyün risk seviyesi fon performansı belirlenirken baz alınması gereken temel faktörlerdir.

Sistematik riskleri $(\beta)$ farklı olan fonların piyasadaki değişimlere karşı olan duyarlııkları farklıdır. Yüksek betaya sahip bir fon grubunun piyasadaki değişimlere hassasiyeti daha yüksek olduğu için, piyasa getirisi arttığı zaman, fon grubu da yüksek getiri sağlayabilmekte; piyasa getirisi azaldığı zaman, fon grubu da düşük getiriye sahip olabilmektedir. Bu sebeple, bir fonun yüksek getirisinin olması, mutlaka yüksek performans sergilediği anlamına gelmemektedir. Piyasadaki herhangi bir olumsuzlukta yüksek betaya sahip fon grubu da bundan olumsuz olarak etkilenecektir. Dolayısıyla, yüksek risk alındığı zaman, fonun sadece getirisi düşünüldüğünde, piyasaya göre kötü performans sergileme intimali de vardır. Aynı şekilde, düşük betaya sahip bir fon grubunun piyasadaki değişimlere hassasiyeti de düşük olduğu için, piyasa getirisi arttığı zaman, fon grubu, yüksek betaya sahip fon gruplarına göre, getiri bazında daha az bir yükselişe sahip olmakta; piyasa getirisi azaldığı zaman, yüksek betaya sahip fon gruplarına göre getiri bazında daha az bir düşüşe sahip olabilmektedir. Dolayısıyla, bir fonun performansı sadece getiri düzeyine göre değerlendirilmemeli, yatıııın risk boyutu da göz önünde bulundurulmalıdır. Yani fon performansı değerlendirilirken kullanılan ölçüt, maruz kalınan 
riski de hesaba katmalıdır. Bu yüzden, çalışmada fon performanslarının ölçümünde sistematik riske karşı düzeltilmiş getiriyi hesaplamaya olanak veren Jensen Alfa performans ölçütünden yararlanılmıştır.

Jensen (1968) tarafından geliştirilen Jensen Alfa ölçütü SVFM temel alınarak oluşturulmuştur. Jensen Alfa ölçütü fon performanslarını riske göre düzeltilmiş olarak karşılaştırmaktadır. Söz konusu modelde alfa $(\alpha)$, fonun getirisi ile menkul kıymet piyasa doğrusu baz alınarak fonun olması gereken getirisi arasındaki farkı göstermektedir. Bu sebeple, bu modelin amacı gerçekleşmiş olan riske göre fonun beklenen getirisini hesaplayarak gerçekleşen getirisiyle karşılaştırmaktır. Dolayısıyla, menkul kıymet doğru bir şekilde fiyatlandıysa risk priminden daha fazla veya daha az bir getiri sağlamayacak, alfa değeri sıfır olacaktır. Alfa değerlerinin istatistiksel olarak sıfırdan farklı olmaması fonların doğru bir şekilde fiyatlandığını ve anormal getiri sağlamadığını göstermektedir.

Jensen Alfa ölçütünün kullanılmasının önemli sebeplerinden biri de, fonların karşılaştırılmasına dayanan bir performans ölçümünün yanında mutlak bir ölçütün de kullanılmış olmasıdır. Fonların mutlak bir ölçüte göre değerlendirilmesi, her birinin belli bir ölçüte göre değerlendirilmesi anlamına gelmektedir. Yani fonların birbirleriyle karşılaştırılmasından çok, belli bir kritere göre ayrı ayrı değerlendirilmesi söz konusudur. Fonlar birbirleriyle karşılaştırılırken, mutlak bir ölçüte göre değerlendirilmediğinde, sadece aralarında karşılaştırılma yapılabilmekte ve biri diğerine göre daha başarılı veya başarısız sayılabilmektedir. Hâlbuki fonların her ikisi de piyasa getirisine göre daha az (negatif) getiri sağladığında, ikisi de piyasaya göre düşük performans sergilemesine rağmen, biri diğerine göre başarılı sayılabilmekte; bu durum da fonların yanlış değerlendirilmesine sebep olabilmektedir. Bu nedenle, fonların belli bir kritere göre değerlendirilmeleri hem performanslarının kendi içinde değerlendirilmesine hem de birbirleriyle doğru bir şekilde karşılaştırılmalarına yol açmaktadır. Bu çalışma kapsamında, sadece fonların birbirlerine olan üstünlüklerine bakılmamış; ayrıca fon performansları mutlak bir ölçüte göre ayrı ayrı değerlendirilmiştir. Bu noktada alfa söz konusu mutlak ölçüt için kullanılmaktadır.

Fon performanslarının ölçülmesinin hedeflendiği bu çalışmada alfa değeri iki ayrı modelden yararlanılarak tahminlenmiştir. Öncelikle SVFM kullanılmış, ardından SVFM'nin sonuçlarının tutarlılığının test edilmesi amacıyla Fama ve French (1993) üç faktör modelinden yararlanılmıştır.

\subsection{Sermaye Varlıklarını Fiyatlama Modeli'ne Göre Jensen Alfa}

Sharpe (1964), Lintner (1965) ve Mossin (1966) tarafından Markowitz'in (1952) modern portföy teorisi temel alınarak geliştirilen Jensen Alfa, öncelikle SVFM kullanılarak tahmin edilmiştir. SVFM, riskli ya da risksiz varlıkların beklenen getiri ve risk oranı arasındaki ilişkinin belli hipotezlerle ortaya konulabilmesi açısından oldukça önemli ve işlevsel bir modeldir. Portföyün beklenen getirisi ile portföy riskinin hesaplanması için gerekli olan veri sayısını oldukça azaltan SVFM, Denklem (3)'de ifade edilmiştir.

$$
E\left(r_{i}\right)=r_{f}+\beta_{i}\left[E\left(r_{m}\right)-r_{f}\right]
$$


Denklemde $E\left(r_{i}\right) i$ varlığının beklenen getiri oranını, $r_{f}$ risksiz faiz oranını, $E\left(r_{m}\right)$ piyasa portföyünün beklenen getiri oranını ve $b_{i} i$ varlığının sistematik riskini, göstermektedir. Beta $(\beta)$ katsayısı herhangi bir varlığın piyasa portföyüne olan duyarlılığını gösteren bir parametredir. Piyasa portföyü, piyasadaki tüm varlıklara yapılan yatırımdan oluşmaktadır ve çok iyi çeşitlenmiş bir portföydür. Bu sebeple, toplam riski oluşturan firma riski ve piyasa riski bileşenlerinden firma riski tamamıla ortadan kalkmaktadır. Bu sebeple, $\beta$ sadece piyasa riskini göstermektedir.

Çalışma kapsamında, fonların giderleri dâhil edilerek fonların getirileriyle piyasa getirisi arasındaki ilişki analiz edilmiş, benzerlik veya farklılıkları saptanmaya çalışılmıştır. Her bir fon ve fon toplamlarının işlem gördüğü gün ve ay için, SVFM kullanılarak Denklem (4)'te ifade edilen regresyon analizi yapılmıştır. Böylece fon getirilerinin piyasa getirisinden farklılaşıp farklılaşmadığı, fon giderleri de dâhil edilerek belirlenmeye çalışılmıştır.

$$
R_{i t}=\alpha_{i}+\beta_{i}\left(R_{M t}\right)+\varepsilon_{i t}
$$

Denklemde $R_{i t}\left(r_{i t}-r_{f}\right) i$ varlığının $t$ dönemindeki artık getiri oranını, $R_{M t}\left(r_{m t}-r_{f t}\right) t$ dönemindeki piyasa risk primini, $\alpha_{i} i$ varlığının alfa değerini, $b_{i} i$ varlığının beta katsayısını ve $\varepsilon_{i t} i$ varlığının $t$ dönemi için regresyondaki hata terimini göstermektedir. Söz konusu regresyon analizi, günlük ve aylık veri setleriyle oluşturulan her bir fon tipi ile A - B Tipi fon toplamları ve Emeklilik fonu toplamları için ayrı ayrı uygulanmıştır.

Öncelikle günlük analize tabi tutulan fonların artık net getiri oranları hesap edilirken, her bir gün için fonların toplam değerleri kullanılarak Denklem (1)'den günlük ham getiri oranları elde edilmiştir. Ardından fonlara ait gider verileri her bir fon için elde edildikten sonra, o fona ait toplam değere bölünerek bir fona ait toplam değerin ne kadarlık bir oranının giderden oluştuğu hesaplanmış, bir başka deyişle gider oranları bulunmuştur. Bir fona ait yıllık gider oranı, o fonun bir yılda işlem gördüğü güne bölünerek günlük gider oranı hesap edilmiştir. Bu gider oranları da daha önce hesap edilen ham getiri oranlarından Denklem (5)'teki gibi çıkarılarak her bir fona ait net getiri oranı değerleri elde edilmiştir. Elde edilen getiri oranlarından daha önce hesaplanan risksiz faiz oranları çıkarılarak fona ait artık net getiri oranı bulunmuştur.

$$
R_{i t}=(\text { Ham getiri oranl }- \text { Gider oranl })-r_{f t}
$$

Hesaplanan artık net getiri oranı, regresyon denkleminde bağımlı değişken olarak yerini almıştır. BIST 100 getiri endeksi (XU100) için getiri oranları Denklem (1)'e göre hesaplanmıştır. Bu hesaplamada endekse ait Türk lirası cinsinden kapanış değerleri (2. seans) kullanılmıştır. Endeksin günlük getiri oranından risksiz faiz oranı çıkarılarak elde edilen piyasa risk primi, regresyon denkleminde bağımsız değişken olarak yerini almıştır. Fonların hesaplanan günlük getiri oranları ile piyasa endeksine ait günlük getiri oranları arasında Denklem (4) ile gösterilen regresyon analizi uygulanmıştır. Günlük frekansta gerçekleştirilen bu analizler, her bir fon ve fon toplamları için ayrıca aylık frekansta da yapılmıştır. Regresyon denklemlerinden tahmin edilen regresyon sabiti olan Jensen Alfa'nın istatistiksel olarak sıfırdan farklı olup olmadığı test edilerek, fonların riske göre düzeltilmiş anormal bir getiri sağlayıp sağlamadıkları test edilmiştir. 


\subsection{Fama - French Üç Faktör Modeli’ne Göre Jensen Alfa}

Çalışmanın bu bölümünde Jensen Alfa, Fama ve French (1993) tarafından ortaya çıkarılıp uygulanan üç faktör modeli kullanılarak tahmin edilmiştir. Fama ve French (1993) yaptıkları çalışmada hisse senedi getirileri üzerinde, zamana bağı olarak, piyasa portföyünün getirisinin yanında hisse senedi piyasa değeri ve 'defter değeri / piyasa değeri' oranının da etkili olduğunu göstermişlerdir. Böylece önceki bölümde SVFM kullanılarak elde edilmiş sonuçların tutarlılığı farklı bir model kullanılarak test edilmiştir. Yukarıda bahsedilen bu iki faktörün de dâhil edilmesiyle oluşturulan Denklem (6)'daki üç faktör modeli, alfanın tahmin edilmesinde alternatif bir yol olarak kullanılmıştır.

$$
R_{i t}=\alpha_{i}+\beta_{i}\left(R_{M t}\right)+s_{i}\left(S M B_{t}\right)+h_{i}\left(H M L_{t}\right)+\varepsilon_{i t}
$$

Denklemde $R_{i t} i$ varlığının $t$ dönemindeki artık getiri oranını, $R M_{t}$ piyasanın $t$ dönemindeki risk primini, $S M B_{t}$ (Small Minus Big) küçük ve büyük piyasa değerine sahip hisse senedi portföylerinin $t$ dönemindeki getirileri arasındaki farkı, $H M L_{t}$ (High Minus Low) yüksek ve düşük fiyat kazanç oranına sahip hisse senedi portföylerinin $t$ dönemindeki getirileri arasındaki farkı, $b_{i} i$ varlığının artık getirisinin piyasanın artık getirisine olan duyarlıığını, $s_{i} i$ varlığının artık getirisinin $S M B$ faktörüne olan duyarlılığını ve $h_{i} i$ varlığının artık getirisinin $H M L$ faktörüne olan duyarlılığını göstermektedir.

SVFM ile sadece piyasa risk primi baz alınarak performans analizi yapılan fonların, FamaFrench 3 faktör modeli kullanıldığında nasıl bir performans göstereceği çalışmanın bu bölümünde analiz edilmiştir. 3 faktörü meydana getiren faktörlerden $S M B$ ve $H M L^{\prime}$ un oluşturulabilmesi için BIST'de işlem gören hisse senetlerinin çeşitli verilerine ihtiyaç duyulmuştur. Bu faktörler oluşturulurken hisse senetlerinin piyasa değerleri ve fiyat kazanç oranları temel alınmıştır. Bu aşamada, Fama ve French $(1993,1996)$ 'in kullanmış olduğu portföy oluşturma uygulaması izlenmiştir.

Çalışma kapsamında, Thomson Reuters Eikon veri kaynağından alınan 239 hisse senedine ait veriler arasındaki toplam getiri endekslerinden, Denklem (1) kullanılarak, hisse senetlerinin günlük getiri oranları elde edilmiştir. Bu aşamada, öncelikle $S M B$ ve $H M L$ faktörlerine ait portföy getirileri oluşturulmuştur. Bu getiriler oluşturulurken, önce $S M B$ faktörü için eşit ve değer ağırıklı getiri hesabı; ardından $H M L$ faktörü için eşit ve değer ağırlıklı getiri hesabı yapılmıştır. Eşit ağırlıklı getiri, bir portföyü oluşturan hisse senetleri getirilerinin ortalaması alınarak bulunmuştur. Değer ağılıklı getiri ise, bir portföyü oluşturan hisse senetlerinin piyasa değeri ve getiri çarpımları toplamının hisse senetlerinin tümünün toplam piyasa değerine bölünmesiyle hesaplanmıştır.

Faktörlerin oluşturulması aşamasında öncelikle $S M B$ faktörü için portföyler meydana getirilmiştir. Bu amaç doğrultusunda, tüm hisse senetleri piyasa değerlerine göre büyükten küçüğe doğru sıralanmış ve eşit sayıda (veya olabildiğince en yakın sayıda) hisse senedi içeren üç portföy oluşturulmuştur. Bu oluşumdan sonra, en büyük ve en küçük piyasa değerine sahip portföyün eşit ağırlıklı ve değer ağırlıklı ortalama getirileri hesap edilmiştir. Ardından, piyasa değeri küçük olan hisse senetlerinin oluşturduğu portföylerin ortalama getirilerinden, piyasa değeri büyük olan hisse senetlerinin oluşturduğu portföylerin ortalama getirileri çıkarılarak, SMB faktörüne ait getiriler eşit ağırlıklı ve değer ağırlıklı 
olacak şekilde iki farklı ağırlıklandırma yöntemi ile bulunmuştur. Bu işlem, 2001 yılının ilk iş gününden 2011 yılının son iş gününe kadar her iş günü için ayrı ayrı tekrarlanmış ve her güne ait uç portföyler arasındaki ortalama getiri farkları hesaplanarak SMB faktörü elde edilmiştir. $H M L$ faktörü oluşturulurken de aynı yöntem uygulanmış fakat bu sefer hisse senetleri fiyat kazanç oranlarına göre yüksekten düşüğe doğru sıralanmış ve üç portföy oluşturulmuştur. En yüksek ve en düşük fiyat kazanç oranına sahip portföylerin ortalama getirileri arasındaki fark hesaplanarak, $H M L$ faktörü günlük frekansta hem eşit ağırlıklı hem de değer ağırlıklı olarak hesaplanmıştır.

Jensen Alfa tahmin edilirken, eşit ağırlıklı ve değer ağırlıklı olarak hesaplanmış $S M B$ ve $H M L$ faktörleri ayrı faktör grupları olarak iki farklı regresyon analizine dâhil edilmiş ve sonuçlar her iki farklı ağırlıklandırma yöntemi için raporlanmıştır. Ayrıca, söz konusu faktörler aylık frekansta da oluşturulmuş ve faktör oluşumunda günlük olarak yapılan tüm bu işlemler, her bir fon ve fon toplamları için aylık olarak da tekrarlanmıştır.

\section{BULGULAR}

Fonların performans ölçümü yapılırken riske göre düzeltilmiş getiriyi gösteren Jensen Alfa ölçütü, söz konusu fonların getirileri ve ilgili faktörler arasında yapılan regresyon denkleminde tahminlenen sabit terim $(\alpha)$ olarak hesaplanmıştır. Pozitif alfa değeri riske göre düzeltilmiş yüksek performansı ifade ederken, negatif alfa değeri de riske göre düzeltilmiş düşük performansı göstermektedir. Performans değerlendirmesi yapılırken alfanın sıfırdan farklı olup olmadığı test edilmiştir. Bu amaçla, hem pozitif hem de negatif performansın söz konusu olabileceği düşünülerek iki taraflı ' $\mathrm{t}$ ' testi kullanılmıştır. Ele alınan fonlar SVFM ile ayrı ayrı günlük ve aylık regresyon analizi tabi tutulmuş ve veri frekansları için performans değerlendirmeleri yapılmıştır.

\subsection{Günlük Veriler Kullanılarak Elde Edilen Bulgular}

SVFM analizi kapsamında, yatırım ve emeklilik fonları Ocak 2001 - Aralık 2011 tarih aralığı için günlük bazda analize tabi tutulmuştur. Böylece yatırım fonlarının performansı farklı yatırım ufkuna sahip yatırımcılar içinde değerlendirilmiş olacaktır.

Tablo 5, SVFM kullanılarak oluşturulan ve Denklem (4) ile ifade edilen regresyon denkleminin günlük veriler kullanılarak tahmin edilmesiyle elde edilen regresyon katsayısı ve sabiti tahminlerini ve t-istatistiklerini göstermektedir. Tablo 5 'de yer alan her bir fon tipi, A - B Tipi fon toplamları ve Emeklilik fonu toplamlarının oluşturduğu 21 tane fon grubundan, 12 fon grubunda alfa değerinin pozitif olduğu görülmektedir ( $A$ Tipi endeks, $A$ Tipi fon sepeti, A Tipi karma, B Tipi (toplam), B Tipi altın, B Tipi endeks, B Tipi fon sepeti, B Tipi karma, B Tipi likit, B Tipi özel, B Tipi yabancı menkul kıymetler ve Emeklilik (toplam) fonu). Fakat bu fonlardan sadece 4 fon grubu için pozitif ve istatistiksel olarak anlamlı alfa değerleri elde edilmiştir. Bu fonlar, B Tipi altın fon, B Tipi karma fon, B Tipi özel fon ve Emeklilik (toplam) fonudur. Yani, bu fon grupları, risklerine göre sağlamaları gerekenden daha fazla bir getiri sağlamışlar ve yüksek performans sergilemişlerdir. Geriye kalan 17 fon grubu, fon giderleri de ele alındığında, pozitif anormal getiri sağlamamıştır. Yani, incelenen fon gruplarının büyük çoğunluğunda, beklenenin aksine, profesyoneller tarafından yönetilen yatırım fonlarının daha yüksek bir performans göstermedikleri bulunmuştur. 
Hatta İstatistiksel olarak anlamlı çıkan diğer 1 fon grubunun (A Tipi değişken) negatif bir alfaya sahip olduğu görülmüş ve riskine göre sağlaması gereken getiriyi kazandırmadığı tespit edilmiştir.

\section{Tablo 5: Fon Gruplarının Günlük SVFM ile Performans Testi}

Ocak 2001 - Aralık 2011 tarih aralığında günlük bazda uygulanan SVFM regresyon denklemi $R_{i t}=\alpha_{i}+\beta_{i}\left(R_{M t}\right)+\varepsilon_{i t}$ sonuçları gösterilmektedir. Parantez içinde t-

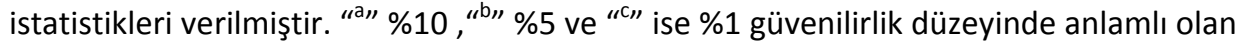
değişkenleri göstermektedir.

\begin{tabular}{|c|c|c|c|}
\hline Fonlar & $\alpha$ & Fonlar & $\alpha$ \\
\hline \multirow[t]{2}{*}{ A Tipi Değişken } & $-0.00^{b}$ & \multirow[t]{2}{*}{ B Tipi Altın } & $0.00^{c}$ \\
\hline & $(-2.23)$ & & (3.94) \\
\hline \multirow[t]{2}{*}{ A Tipi Endeks } & 0.00 & \multirow[t]{2}{*}{ B Tipi Değişken } & -0.00 \\
\hline & $(0.23)$ & & $(-1.30)$ \\
\hline \multirow[t]{2}{*}{ A Tipi Fon Sepeti } & 0.00 & \multirow[t]{2}{*}{ B Tipi Endeks } & 0.00 \\
\hline & $(0.82)$ & & $(0.17)$ \\
\hline \multirow[t]{2}{*}{ A Tipi Hisse Senedi } & -0.00 & \multirow[t]{2}{*}{ B Tipi Fon Sepeti } & 0.00 \\
\hline & $(-1.30)$ & & $(0.57)$ \\
\hline \multirow[t]{2}{*}{ A Tipi İştirak } & -0.00 & \multirow[t]{2}{*}{ B Tipi Karma } & $0.00^{\mathrm{a}}$ \\
\hline & $(-0.50)$ & & $(1.69)$ \\
\hline \multirow[t]{2}{*}{ A Tipi Karma } & 0.00 & \multirow[t]{2}{*}{ B Tipi Likit } & 0.00 \\
\hline & $(0.22)$ & & $(0.73)$ \\
\hline \multirow[t]{2}{*}{ A Tipi Özel } & -0.00 & \multirow[t]{2}{*}{ B Tipi Özel } & $0.00^{c}$ \\
\hline & $(-0.88)$ & & $(2.98)$ \\
\hline \multirow[t]{2}{*}{ A Tipi Sektör } & -0.00 & \multirow[t]{2}{*}{ B Tipi Tahvil Bono } & -0.00 \\
\hline & $(-1.23)$ & & $(-0.42)$ \\
\hline \multirow{2}{*}{$\begin{array}{l}\text { A Tipi Yabancı Menkul } \\
\text { Kıymetler }\end{array}$} & -0.00 & \multirow{2}{*}{$\begin{array}{l}\text { B Tipi Yabancı Menkul } \\
\text { Kıymetler }\end{array}$} & 0.00 \\
\hline & $(-1.31)$ & & $(0.46)$ \\
\hline \multirow[t]{2}{*}{ A Tipi (Toplam) } & -0.00 & \multirow[t]{2}{*}{ B Tipi (Toplam) } & 0.00 \\
\hline & $(-0.81)$ & & $(0.51)$ \\
\hline \multirow[t]{2}{*}{ Emeklilik (Toplam) } & $0.00^{c}$ & & \\
\hline & $(10.06)$ & & \\
\hline
\end{tabular}

\subsection{Aylık Veriler Kullanılarak Elde Edilen Bulgular}

SVFM analizi kapsamında, yatırım ve emeklilik fonları Ocak 2001 - Aralık 2011 tarih aralığı için aylık bazda da analize tabi tutulmuştur. Tablo 6, SVFM kullanılarak oluşturulan ve Denklem (4) ile ifade edilen regresyon denkleminin aylık veriler kullanılarak tahmin edilmesiyle elde edilen regresyon katsayısı ve sabiti tahminlerini ve t-istatistiklerini göstermektedir. 
Tablo 6: Fon Gruplarının Aylık SVFM ile Performans Testi

\begin{tabular}{|c|c|c|c|}
\hline \multicolumn{4}{|c|}{ 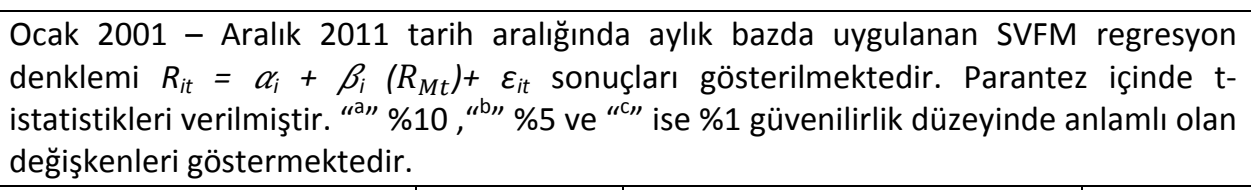 } \\
\hline Fonlar & $\alpha$ & Fonlar & $\alpha$ \\
\hline \multirow[t]{2}{*}{ A Tipi Değişken } & $-0.02^{c}$ & \multirow[t]{2}{*}{ B Tipi Altın } & 0.02 \\
\hline & $(-3.53)$ & & $(1.47)$ \\
\hline \multirow[t]{2}{*}{ A Tipi Endeks } & $-0.01^{\mathrm{a}}$ & \multirow[t]{2}{*}{ B Tipi Değişken } & -0.00 \\
\hline & $(-1.66)$ & & $(-0.43)$ \\
\hline \multirow[t]{2}{*}{ A Tipi Fon Sepeti } & 0.00 & \multirow[t]{2}{*}{ B Tipi Endeks } & -0.00 \\
\hline & $(0.65)$ & & $(-0.88)$ \\
\hline \multirow[t]{2}{*}{ A Tipi Hisse Senedi } & $-0.02^{c}$ & \multirow[t]{2}{*}{ B Tipi Fon Sepeti } & -0.00 \\
\hline & $(-2.96)$ & & $(-0.40)$ \\
\hline \multirow[t]{2}{*}{ A Tipi İştirak } & -0.01 & \multirow[t]{2}{*}{ B Tipi Karma } & $-0.04^{c}$ \\
\hline & $(-1.05)$ & & $(-3.01)$ \\
\hline \multirow[t]{2}{*}{ A Tipi Karma } & $-0.02^{c}$ & \multirow[t]{2}{*}{ B Tipi Likit } & -0.00 \\
\hline & $(-3.80)$ & & $(-0.37)$ \\
\hline \multirow[t]{2}{*}{ A Tipi Özel } & $-0.01^{c}$ & \multirow[t]{2}{*}{ B Tipi Özel } & $0.01^{b}$ \\
\hline & $(-2.64)$ & & $(2.39)$ \\
\hline \multirow[t]{2}{*}{ A Tipi Sektör } & $-0.03^{b}$ & \multirow[t]{2}{*}{ B Tipi Tahvil Bono } & -0.01 \\
\hline & $(-2.55)$ & & $(-1.21)$ \\
\hline \multirow{2}{*}{$\begin{array}{l}\text { A Tipi Yabancı Menkul } \\
\text { Kıymetler }\end{array}$} & $-0.02^{b}$ & \multirow{2}{*}{$\begin{array}{l}\text { B Tipi Yabancı Menkul } \\
\text { Kıymetler }\end{array}$} & $-0.03^{b}$ \\
\hline & $(-2.16)$ & & $(-2.25)$ \\
\hline \multirow[t]{2}{*}{ A Tipi (Toplam) } & $-0.02^{c}$ & \multirow[t]{2}{*}{ B Tipi (Toplam) } & -0.00 \\
\hline & $(-3.86)$ & & $(-0.61)$ \\
\hline \multirow[t]{2}{*}{ Emeklilik (Toplam) } & $0.03^{c}$ & & \\
\hline & $(8.91)$ & & \\
\hline
\end{tabular}

Tablo 6'da yer alan her bir fon tipi, A - B Tipi fon toplamları ve Emeklilik fonu toplamlarının oluşturduğu 21 tane fon grubu; alfa değerleri ve t-istatistikleri göz önünde bulundurularak değerlendirildiğinde, alfa değerinin 4 fon grubunda pozitif olduğu görülmektedir. Bu fon grupları A Tipi fon sepeti, B Tipi altın, B Tipi özel ve Emeklilik (toplam) fonudur. Fakat bu fonlardan sadece B Tipi özel ve Emeklilik (toplam) fonu olmak üzere, 2 fon grubunun alfası pozitif ve istatistiksel olarak sıfırdan farklıdır. Yani, B Tipi Özel ve Emeklilik (toplam) fonları sahip oldukları riske oranla daha yüksek bir getiri sağlayıp, yatırımcılarına anormal getiri elde etme imkânı sunmuşlardır. Geriye kalan 19 fon grubu fon giderleri de ele alındığında, pozitif anormal getiri sağlamamıştır. Hatta istatistiksel olarak anlamlı çıkan diğer 10 fon grubunun negatif bir alfaya sahip olduğu görülmüş ve risklerine göre sağlamaları gereken getiriyi kazandırmadıkları tespit edilmiştir. 


\section{TUTARLILIK TESTLERi}

Yatırım ve emeklilik fonları Ocak 2001 - Aralık 2011 tarih aralığı için hem günlük hem de aylık bazda Fama - French üç faktör analizine tabi tutularak tutarlılık testleri uygulanmıştır. SVFM'den farklı olarak Fama - French üç faktör modeline eşit ve değer ağırıklı olarak hesaplanan $S M B$ ve $H M L$ faktörleri de eklenmiştir. Böylece, SVFM'de elde edilen performans sonuçları için tutarlılık testlerinin oluşturulması hedeflenmiştir. Yer kısıtından dolayı, bu bölümde analiz sonuçlarını gösteren tablolar yer almamıştır. Söz konusu tablolara, istenildiği takdirde yazarlardan ulaşılabilmektedir.

\subsection{Günlük Veriler Kullanılarak Yapılan Tutarlılık Testleri}

Bu bölümde, Fama - French üç faktör modeli kullanılarak oluşturulan ve Denklem (6) ile ifade edilen regresyon denklemi, günlük veriler kullanılarak tahmin edilmiş ve tutarlılık testleri uygulanmıştır. Her bir fon tipi, A - B Tipi fon toplamları ve Emeklilik fonu toplamlarının oluşturduğu 21 tane fon grubu eşit ağırlıklı olarak değerlendirildiğinde alfa değeri; A Tipi fon sepeti, A Tipi karma, A Tipi yabancı menkul kıymetler, B Tipi (toplam), B Tipi altın, B Tipi endeks, B Tipi fon sepeti, B Tipi karma, B Tipi likit, B Tipi özel, B Tipi yabancı menkul kıymetler ve Emeklilik (toplam) fonunda pozitif çıkmıştır. Fakat bu fonlardan sadece B Tipi altın ve Emeklilik (toplam) fonu olmak üzere, 2 fon grubunun alfası pozitif ve istatistiksel olarak sıfırdan farklıdır. Alfası pozitif fakat istatistiksel olarak anlamlı olmayan kalan 10 fon grubu, fon giderleri de ele alındığında, pozitif anormal getiri sağlamamıştır. İstatistiksel olarak anlamlı çıkan diğer 2 fon grubunun (A Tipi değişken fonu ve A Tipi sektör fonu) negatif bir alfaya sahip olduğu görülmüş ve risklerine göre sağlamaları gereken getiriden daha az kazandırdıkları tespit edilmiştir.

Her bir fon tipi, A - B Tipi fon toplamları ve Emeklilik fonu toplamlarının oluşturduğu 21 tane fon grubu değer ağırlıklı olarak alfa değerleri ve t-istatistikleri göz önünde bulundurularak değerlendirildiğinde, alfa değerinin 12 fon grubunda pozitif olduğu görülmektedir. Bu fon grupları A Tipi fon sepeti, A Tipi karma, A Tipi yabancı menkul kıymetler, B Tipi (toplam), B Tipi altın, B Tipi endeks, B Tipi fon sepeti, B Tipi karma, B Tipi likit, B Tipi özel, B Tipi yabancı menkul kıymetler ve Emeklilik (toplam) fonudur. Fakat bu fonlardan sadece B Tipi altın ve Emeklilik (toplam) fonunun alfası pozitif ve istatistiksel olarak sıfırdan farklıdır. Geriye kalan 19 fon grubu fon giderleri de ele alındığında, pozitif anormal getiri sağlamamıştır. Hatta istatistiksel olarak anlamlı çıkan diğer 1 fon grubunun (A Tipi değişken fonu) negatif bir alfaya sahip olduğu görülmüş ve riskine göre sağlaması gereken getiriyi kazandırmadığı tespit edilmiştir.

\subsection{Aylık Veriler Kullanılarak Yapılan Tutarlılık Testleri}

Bu bölümde, Fama - French üç faktör modeli kullanılarak oluşturulan ve Denklem (6) yoluyla yapılan regresyon analizleri sonucunda aylık tahminler elde edilmiş ve tutarlılık testleri yapılmıştır. Her bir fon tipi, A - B Tipi fon toplamları ve Emeklilik fonu toplamlarının oluşturduğu 21 tane fon grubu; alfa değerleri ve t-istatistikleri göz önünde bulundurularak eşit ağırlıklı olarak değerlendirildiğinde, alfa değerinin 8 fon grubunda pozitif olduğu görülmektedir. Bu fon grupları A Tipi fon sepeti, A Tipi yabancı menkul kıymetler, B Tipi 
altın, B Tipi karma, B Tipi likit, B Tipi özel, B Tipi yabancı menkul kıymetler ve Emeklilik (toplam) fonudur. Fakat bu fonlardan sadece B Tipi özel ve Emeklilik (toplam) fonu olmak üzere, 2 fon grubunun alfası pozitif ve istatistiksel olarak sıfırdan farklıdır. Geriye kalan 19 fon grubu fon giderleri de ele alındığında, pozitif anormal getiri sağlamamıştır. Hatta istatistiksel olarak anlamlı çıkan diğer 6 fon grubunun (A Tipi (toplam), A Tipi değişken fonu, A Tipi hisse senedi fonu, A Tipi karma fon, A Tipi özel fon ve A Tipi sektör fonu) negatif bir alfaya sahip olduğu görülmüş ve risklerine göre sağlamaları gereken getiriyi kazandırmadıkları tespit edilmiştir.

Her bir fon tipi ve A - B Tipi fon toplamları ve Emeklilik fonu toplamlarının oluşturduğu 21 tane fon grubu; alfa değerleri ve t-istatistikleri göz önünde bulundurularak değer ağırlıklı olarak değerlendirildiğinde, alfa değerinin 9 fon grubunda pozitif olduğu görülmektedir. Bu fon grupları A Tipi fon sepeti, A Tipi yabancı menkul kıymetler, B Tipi (toplam), B Tipi altın, B Tipi karma, B Tipi likit, B Tipi özel, B Tipi yabancı menkul kıymetler ve Emeklilik (toplam) fonudur. Fakat bu fonlardan, sadece B Tipi özel ve Emeklilik (toplam) fonu olmak üzere, 2 fon grubunun alfası pozitif ve istatistiksel olarak sıfırdan farklıdır. Geriye kalan 19 fon grubu fon giderleri de ele alındığında, pozitif anormal getiri sağlamamıştır. Hatta istatistiksel olarak anlamlı çıkan diğer 5 fon grubunun (A Tipi (toplam) fonu, A Tipi değişken fon, A Tipi hisse senedi fonu, A Tipi karma fon ve A Tipi sektör fonu) negatif bir alfaya sahip olduğu görülmüş ve risklerine göre sağlamaları gereken getiriyi kazandırmadıkları tespit edilmiştir.

\section{SONUÇ}

Çalışma kapsamında, A ve B Tipi yatırım fonları ile Emeklilik ve A - B yatırım fonları toplamından oluşan fon gruplarının Ocak 2001 - Aralık 2011 tarih aralığı için performans ölçümü yapılmış ve bu ölçümde, regresyon denklemlerinde regresyon sabiti olarak kendini gösteren Jensen Alfa ölçütü kullanılmıştır. Regresyon analizleri yapılırken SVFM ve Fama French üç faktör modelinden yararlanılmıştır. Her bir model için hem günlük hem de aylık analizler yapılmış ve fon gruplarının performansları değerlendirilmiştir. Öncelikle SVFM kullanılarak günlük ve aylık dönemlerle analizler yapılmıştır. SVFM günlük ve aylık analiz sonuçlarının her ikisi birden, B Tipi özel ve Emeklilik (toplam) fonlarının piyasaya göre pozitif anormal getiri sağladıklarına işaret etmiştir.

Elde edilen sonuçların kullanılan varlık fiyatlama modeline duyarlı olup olmadığını test etmek amacıyla alternatif model olarak Fama - French üç faktör modeli ele alınmıştır. Ayrıca bu modelde, $S M B$ ve $H M L$ faktörleri hem eşit ağılıklı hem de değer ağırlıklı hesaplanarak sonuçların kullanılan ağılıklandırma yöntemine göre tutarlılıkları da test edilmiştir. Eşit ağırlıklı ve değer ağırlıklı Fama - French günlük analizinin ortak sonucu, B Tipi altın fonu ve Emeklilik (toplam) fonlarının pozitif anormal getiri sağladıklarıdır. Fama French üç faktör modeli için aylık dönemlerle hesaplanan eşit ağırlıklı ve değer ağırlıklı analizlerinin ortak sonucu, eşit ağırlıklı ve değer ağırlıklı Fama - French günlük analizinin sonucunda olduğu gibi Emeklilik (toplam) fonlarının ve buna ek olarak, B Tipi özel fonun, piyasaya göre pozitif anormal getiri sağladıklarıdır.

Yapılan SVFM ve Fama - French üç faktör modeli analizlerinin sonuçlarına göre, 21 fon grubu arasından sadece B Tipi altın, B Tipi özel ve Emeklilik (toplam) fon grupları hemen 
hemen tüm regresyon sonuçlarında yüksek performans göstermişlerdir. Söz konusu fonlara ek olarak, sadece günlük yapılan SVFM analizi sonuçlarında B Tipi karma fon \%10 anlamlılık düzeyi gibi marjinal bir düzeyde, yüksek performans sergilemiştir. Altının fiyatının yıldan yıla aşırı artması sebebiyle, yüksek performans göstermesi sürpriz olmayan bir sonuçtur ve bu yüksek getiriye bireysel yatırım yaparak da ulaşmanın mümkün olduğu düşünülmektedir. B Tipi özel fonlar, hakkında iflas davası açılmış ve tüm yetki belgeleri iptal edilen kurumların alacaklarının ödenmesi sebebiyle kurulmuş olup belli kişi ve kuruluşlara ayrılmış fonlar olduğu için pozitif anormal getiriye sahip olabilmektedir. Çünkü halka açık olmamakla birlikte, tasarrufu zorunlu kılan bir fondur. Emeklilik fonlarının performansının yüksek olması da uzun vadeli yatırım araçları olmasından kaynaklanmış olabilmektedir. B Tipi karma fon için portföyün tamamı, borçlanma araçları, hisse senetleri, altın ve diğer kıymetli menkul kıymetlerden ve bunlara yönelik sermaye piyasası araçlarının en az ikisinden oluştuğu için; B Tipi karma fonun performansının yüksek olması B Tipi altın fonunun performansının yüksek olmasına bağlanabilmektedir. Çünkü B Tipi karma fonun performansının yüksek çıktığı günlük olarak yapılan SVFM analizi sonuçlarına göre, B Tipi altın fonunun da performansı yüksek çıkmıştır ve karma fonu oluşturan varlıkların her birinin değeri portföy değerinin \%20'sinden daha fazladır. Dolayısıyla, performansı yüksek çıkan ve B Tipi altın ile aynı analiz sonuçlarında yer alan B Tipi karma fondaki altının değerinin yüksek olduğu düşünülmektedir. 21 fon grubu arasında sadece 3 tanesinin hemen hemen tüm analizlerde pozitif anormal getiri sağlaması, karakteristik özelliklerinden dolayı yüksek getiri sağlayabileceklerini düşündürmektedir. Dolayısıyla, fon getiri oranları hesap edilirken fon gider oranlarının analize dâhil edilmesi, fonların büyük çoğunluğunun pazar endeksine göre yüksek performans göstermediği sonucunu doğurmuştur.

\section{KAYNAKÇA}

Akel, V. (2007), Türkiye'deki A ve B Tipi Yatırım Fonları Performansının Devamlılığının Parametrik ve Parametrik Olmayan Yöntemlerle Değerlendirilmesi, Dokuz Eylül Üniversitesi İktisadi ve İdari Bilimler Fakültesi Dergisi, 22(2), s.147-177.

Altıntaş, K. M. (2008), Türk Özel Emeklilik Fonlarının Risk Odaklı Yönetim Performansı: 2004-2006 Dönemine ìlişkin Bir Analiz, Anadolu Üniversitesi Sosyal Bilimler Dergisi, 8(1), s.85-110.

Arslan, M. (2005), A Tipi Yatırım Fonlarında Yöneticilerin Zamanlama Kabiliyeti ve Performans İlişkisi Analizi: 2002-2005 Dönemi Bir Uygulama, Ticaret ve Turizm Eğitim Fakültesi Dergisi, 2, s.1-23.

Arslan, M. ve Arslan, S. (2010), Yatırım Fonu Performans Ölçütleri, Regresyon Analizleri ve MANOVA Yöntemine Göre A, B ve Borsa Yatırım Fonlarının Karşılaştırmalı Analizi, İşletme Araştırmaları Dergisi, 2(2), s.3-20.

Aşcı, B. (2012), 2006-2010 Yılları Arasında Türkiye'deki A Tipi Yatırım Fonlarının Performans Değerlendirmesi, Yüksek Lisans Tezi, İstanbul: Doğuş Üniversitesi Sosyal Bilimler Enstitüsü.

Ayaydın, H. (2013), Türkiye'deki Emeklilik Yatırım Fonlarının Performanslarının Analizi, Çukurova Üniversitesi Sosyal Bilimler Enstitüsü Dergisi, 22(2), s.59-80.

Blake, C. R., Elton, E. J. ve Gruber M. J. (1993), The Performance of Bond Mutual Funds, The Journal of Business, 66(3), s.371-403.

Cesarı, R. ve Panetta, F. (2002), The Performance of Italian Equity Funds, Journal of Banking and Finance, 26(1), s.99-126. 
Cumby, R. E. ve Glen, J. D. (1990), Evaluating the Performance of International Mutual Funds, The Journal of Finance, 45(2), s.497-521.

Fama, E. F. ve French, K. R. (1992), The Cross-Section of Expected Stock Returns, The Journal of Finance, 47(2), s.427-465.

Fama, E. F. ve French, K. R. (1993), Common Risk Factors in the Returns on Stocks and Bonds, The Journal of Finance, 33(1), s.3-56.

Gökgöz, F. ve Günel, M. O. (2012), Türk Yatııı Fonlarının Portföy Performanslarının Analizi, Ankara Üniversitesi Sosyal Bilimler Enstitüsü Dergisi, 3(2), DOI: 10.1501.

Grinblatt, M. ve Titman, S. (1989), Mutual Fund Performance: An Analysis of Quarterly Portfolio Holdings, The Journal of Business, 62(3), s.393-416.

Gürsoy, C. T. Ve Erzurumlu, Y. Ö. (2001), Evaluation of Portfolio Performance of Turkish Investment Funds, Doğuş Üniversitesi Dergisi, 4, s.43-58.

Jensen, M. C. (1968), The Performance of Mutual Funds in the Period 1945-1964, The Journal of Finance, 23(2), s.389-416.

Karacabey, A. ve Karatepe, Y. (2000), A Tipi Yatırım Fonları Performansının Yeni Bir Yöntem Kullanılarak Değerlendirilmesi: Graham-Harvey Performans Testi, Ankara Üniversitesi SBF Dergisi, 55(2), s.55-67.

Korkmaz, T. ve Uygurtürk, H. (2007), Türk Emeklilik Fonlarının Performans Ölçümünde Regresyon Analizinin KullanıIması, ZKÜ Sosyal Bilimler Dergisi, 3(5), s.37-52.

Korkmaz, T. ve Uygurtürk, H. (2009), Türkiye'de İslem Gören Hisse Senedi Ağırıklı Yatııım Fonlarının Performans Karşılaştırması, Akademik Araştırmalar ve Çalışmalar Dergisi, 1(1).

Lintner, J. (1965), The Valuation of Risky Assets and the Selection of Risky Investments in Stock Portfolios and Capital Budgets, Review of Economic and Statistics, 47, s.13-37.

Malkiel, B. G. (1995), Returns from Investing in Equity Mutual Funds 1971 to 1991, Journal of Finance, 50(2), s.549-572.

Markowitz, H. (1952), Portfolio Selection. The Journal of Finance, 7(1), s.77-91.

Mossin, J. (1966), Equilibrium in a Capital Asset Market, Econometrica, 34(4), s.768-783.

Omağ, A. (2010), Türkiye'de A Tipi ve B Tipi Yatııım Fonlarının 2000 - 2008 Dönemi Performans Analizi, i̇stanbul Ticaret Üniversitesi Sosyal Bilimler Dergisi, 9(17), s.235-250.

Sermaye Piyasası Kurulu Yatırımcı Bilgilendirme Kitapçıkları, 24 Haziran 2015,

http://www.spk.gov.tr/displayfile.aspx?action=displayfile\&pageid=78\&fn=78.pdf

Sermaye Piyasası Kurulu Yatırımcı Bilgilendirme Kitapçıkları, 1 Temmuz 2015,

http://www.spk.gov.tr/displayfile.aspx?action=displayfile\&pageid=78\&fn=78.pdf\&submenuheader=null

Sermaye Piyasası Kurulu Aylık İstatistik Bülteni, 3 Temmuz 2015, http://spk.gov.tr/apps/aylikbulten/index.aspx

Sharpe, W. F. (1964), Capital Asset Prices: A Theory of Market Equilibrium under Conditions of Risk, The Journal of Finance, 19(3), s.425-442.

Takasbank (Türkiye Sermaye Piyasaları Birliği), 2 Ağustos 2015,

http://www.tspb.org.tr/tr/Portals/0/AIM_Yillik/TSP_2014_web_opt\%20R.pdf

Yolsal, H. (2012), A Tipi Yatırım Fonlarının Performansı: Banka ve Aracı Kurum Fonları Üzerine Bir İnceleme, Marmara Üniversitesi i.i.B.F. Dergisi, 32(1), s.343-364. 